\title{
The supplementary therapeutic DMARD role of low-dose glucocorticoids in rheumatoid arthritis
}

\author{
Maurizio Cutolo*1, Cornelia M Spies², Frank Buttgereit², Sabrina Paolino and Carmen Pizzorni
}

\begin{abstract}
The management of rheumatoid arthritis (RA) is primarily based on the use of disease-modifying antirheumatic drugs (DMARDs), mainly comprising synthetic chemical compounds (that is, methotrexate or leflunomide) and biological agents (tumor necrosis factor inhibitors or abatacept). On the other hand, glucocorticoids (GCs), used for decades in the treatment of RA, are effective in relieving signs and symptoms of the disease, but also interfere with radiographic progression, either as monotherapy or in combination with conventional synthetic DMARDs. GCs exert most of their biological effects through a genomic action, using the cytosolic GC receptor and then interacting with the target genes within target cells that can result in increased expression of regulatory - including anti-inflammatory proteins (transactivation) or decreased production of proinflammatory proteins (transrepression). An inadequate secretion of GCs from the adrenal gland, in relation to stress and inflammation, seems to play an important role in the pathogenesis and disease progression of RA. At present there is clear evidence that GC therapy, especially long-term low-dose treatment, slows radiographic progression by at least $50 \%$ when given to patients with early RA, hence satisfying the conventional definition of a DMARD. In addition, long-term follow-up studies suggest that RA treatment strategies which include GC therapy may favorably alter the disease course even after their discontinuation. Finally, a low-dose, modified night-release formulation of prednisone, although administered in the evening (replacement therapy), has been developed to counteract the circadian (night) rise in proinflammatory cytokine levels that contributes to disease activity, and might represent the way to further optimize the DMARD activity exerted by GCs in RA.
\end{abstract}

\section{Introduction}

Rheumatoid arthritis (RA) is a multifactorial, chronic inflammatory and immune-mediated syndrome that causes joint damage, but can in selected patients present with different tissue and organ involvement [1]. Following the 2010 American College of Rheumatology/European League Against Rheumatism RA classification criteria, an overall score $\geq 6 / 10$ is needed for classification of a patient as having RA [2]. However, these criteria should only be used if a clinical case of RA is likely; namely the patient should have at least one joint with a definite clinical synovitis, not explained by another disease.

The sensitivity of these criteria was recently measured to be higher than its precursor of 1987 while having a lower specificity [3]. Notably, in RA chronic synovial tissue inflammation and hyperplasia drive articular

*Correspondence: mcutolo@unige.it

'Research Laboratory and Academic Division of Clinical Rheumatology,

Department of Internal Medicine, University of Genova, Viale Benedetto XV 6,

16132 Genova, Italy

Full list of author information is available at the end of the article destruction and bone erosion, leading to functional decline and disability [4].

Biological disease-modifying antirheumatic drugs (DMARDs) target particular soluble extracellular mediators (that is, cytokines) or cell surface molecules (that is, CD20 or CD86) with high specificity [5]. Conversely, conventional synthetic DMARDs usually act within cells, but nonetheless may also have specific targets such as that designed to target Janus kinases and constituting the first targeted synthetic DMARD, named tsDMARD, following a proposed new nomenclature [6].

On the other hand, glucocorticoids (GCs), used for decades in the treatment of RA, are effective in relieving signs and symptoms of the disease and also interfere with radiographic progression, either as monotherapy or in combination with synthetic DMARDs [7]. An inadequate secretion of GCs from the adrenal gland, in relation to stress and inflammation, seems to play an important role in the pathogenesis and disease progression of RA. [7] As a matter of fact, in the most recent European League Against Rheumatism (EULAR) recommendations for the management of RA, low-dose GCs have been confirmed as at least part of the initial treatment strategy (in 
combination with one or more conventional synthetic DMARDs) for at least 6 months [8].

\section{Understanding the anti-inflammatory actions of glucocorticoids}

Despite being among the most effective anti-inflammatory treatments for chronic inflammatory diseases, the mechanisms by which GCs effect repression of inflammatory gene expression remain only incompletely understood. Direct interaction of the GC receptor (nuclear receptor subfamily 3 , group $\mathrm{C}$, member 1 (NR3C1)) with inflammatory transcription factors to repress transcriptional activity - that is, transrepression - represents one mechanism of action. However, transcriptional activation - or transactivation - by the GC receptor (NR3C1) also represents an important mechanism of GC action. In addition, GCs rapidly and profoundly increase expression of multiple genes, many with properties consistent with the repression of inflammatory gene expression [9]. On the other hand, RNA-binding proteins and microRNA play an important role in the pathophysiology of chronic inflammation, and seem to have promising value as mechanisms conveying the antiinflammatory effect of exogenous GCs [10].

In general, GCs provide inhibition of any inflammatory process that seems to be dose dependent, and both a long-term genomic and a short-term nongenomic effect are recognized [11]. Of course, the known side effects of GCs are strongly dose dependent: the longer the therapy or the higher the dose, the more relevant the GC side effects appear [12]. The nomenclature for different GC dosages is reported in Figure 1.

\section{Genomic action of glucorticoids}

As mentioned, and regarding the genomic action, GCs provide most of their effects using the cytosolic glucocorticoid receptor (cGR) - being part of a multiprotein receptor complex also consisting of heat shock proteins and several kinases $[13,14]$.

Since GCs are lipophilic, they are able to pass through the plasma membrane and interact with their distinct receptor within the cells. Of note, the 17-hydroxy, 21-carbon steroid configuration of GCs is the reason for their lipophilicity and the successive receptor binding, and is applicable to both prednisone and prednisolone and other GCs [15].

Following the GC binding to the cGR, the receptorassociated proteins dissociate and the complex of GC/ cGR translocates into the nucleus, binding as a homodimer to specific DNA binding sites, so-called GC response elements [13]. This genomic action, termed transactivation, leads to the synthesis of anti-inflammatory proteins (such as, for example, annexin (lipocortin) 1 , ІкB, interleukin (IL)-10) as well as regulatory proteins, involved also in metabolism and various $\mathrm{GC}$ side effects. On the other hand, GC/cGR monomers are able to negatively interfere with transcription factors (genomic action termed transrepression) such as nuclear factor- $\mathrm{k} \mathrm{B}$, activator protein-1 and nuclear factor for activated $\mathrm{T}$ cells, as a consequence reducing the expression of proinflammatory proteins such as IL-1, IL-6 or tumor necrosis factor (TNF) alpha [16,17]. Interestingly, by decreasing TNF $\alpha$ synthesis, GCs probably lead to reduction of inflammatory osteoporosis and joint erosions since TNF physiologically induces the production of receptor activator of nuclear factor- $\mathrm{kB}$ ligand that appears to be involved in generation of joint erosions by activating osteoclasts [18].

In conclusion, transrepression and transactivation seem to provide the genomic anti-inflammatory actions exerted especially by low-dose prednisone [19]. A lowdose, modified-release formulation of prednisone, administered in the evening, has been developed to counter the circadian rise in proinflammatory cytokine levels that contributes to disease activity and seems to not interfere with the hypothalamic-pituitary-adrenal (HPA) function $[20,21]$. Modified-release prednisone might therefore represent the way to further optimize the DMARD activity exerted by low-dose GCs in RA [22].

\section{Nongenomic action of glucocorticoids}

The administration of prednisone, especially at high dosages, induces a rapid clinical improvement that is sometimes too fast to be explained by genomically mediated action, and the presence of nongenomic action is emphasized by the fact that the cGRs are completely occupied when administering 100 to $200 \mathrm{mg}$ /day prednisone [23,24] (Figure 1).

The proposed nongenomic action for mechanisms that are not cGR-mediated includes their specific interaction with the cGR - resulting, for example, in nongenomic inhibition of arachidonic acid release - and physiochemical interactions with cellular membranes, resulting in nongenomic compromising of ion cycling across the membranes and cell energy supply, and consequently immune/inflammatory cell function [16,25]. Generally, the rapid nongenomic GC effects that appear quickly, from several seconds to minutes, seem to be obtained by three different mechanisms: physicochemical interactions with components of the cellular membranes (nonspecific nongenomic effects); membrane-bound GC receptor-mediated nongenomic effects; and cGRmediated nongenomic effects $[11,26]$. The extraordinary wide range of GC actions can be explained by GC receptor presence in three cell compartments: nucleus, cytoplasm, and plasma membrane (Figure 2).

Whereas the optimization of the genomic action (by low-dose administration) is achieved via GC nighttime 


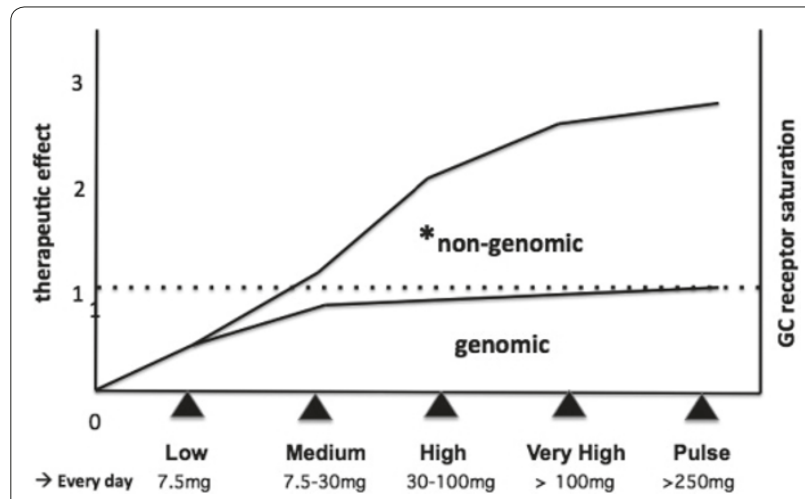

Figure 1. Relationship between different glucocorticoid doses (prednisone equivalent milligrams), intensity of the therapeutic effect (arbitrary units), and genomic/nongenomic mechanism of action. Low-dose therapy, $<7.5 \mathrm{mg} /$ day; medium-dose therapy, 7.5 up to $30 \mathrm{mg} /$ day; high-dose therapy, 30 up to $100 \mathrm{mg} /$ day; very high-dose therapy, >100 mg/day; pulse therapy, >250 mg/day for a few days [12]. *When administering 100 to $200 \mathrm{mg}$ prednisone per day, all cytosolic glucocorticoid (GC) receptors are occupied (nongenomic action) [23].

availability (modified-release prednisone release around 3:00 a.m.), by respecting the circadian rhythm of both endogenous GC synthesis and night activation of the immune/inflammatory reaction, on the other hand the nongenomic action (high doses) should be obtainable at almost any time of the day when fast effects are required [27-30].

\section{From the early steps to the more recent evidence for the use of low-dose glucocorticoids in RA}

The introduction of GCs for treatment of RA in 1948 and the dramatic clinical responses in a report published in 1949 originated the attribution of the Nobel Prize in Physiology and Medicine to Hench, Kendall and Reichstein. Interestingly, the Mayo Clinic group that discovered GCs recommended as early as 1955 that doses equivalent to 5 to $10 \mathrm{mg} /$ day prednisone should be used in treatment of RA [31]. However, a dose of $20 \mathrm{mg} /$ day prednisolone was used in clinical trials in 1960 (after GCs were available for treatment) to compare with aspirin, and while DMARD properties were well documented in RA patients, the conventional wisdom at that time was that low doses were not disease modifying (that is, did not decrease joint damage as assessed radiographically) $[32,33]$.

Therefore, by the late 1950s, oral GCs were considered appropriate in RA only for severe, potentially lifethreatening situations or as short-term bridging therapy while awaiting results of what was regarded as remissioninducing DMARD therapy [34]. However, the first clinical trial involving low-dose GCs was reported in the early 1960s, and compared the evening dose versus the

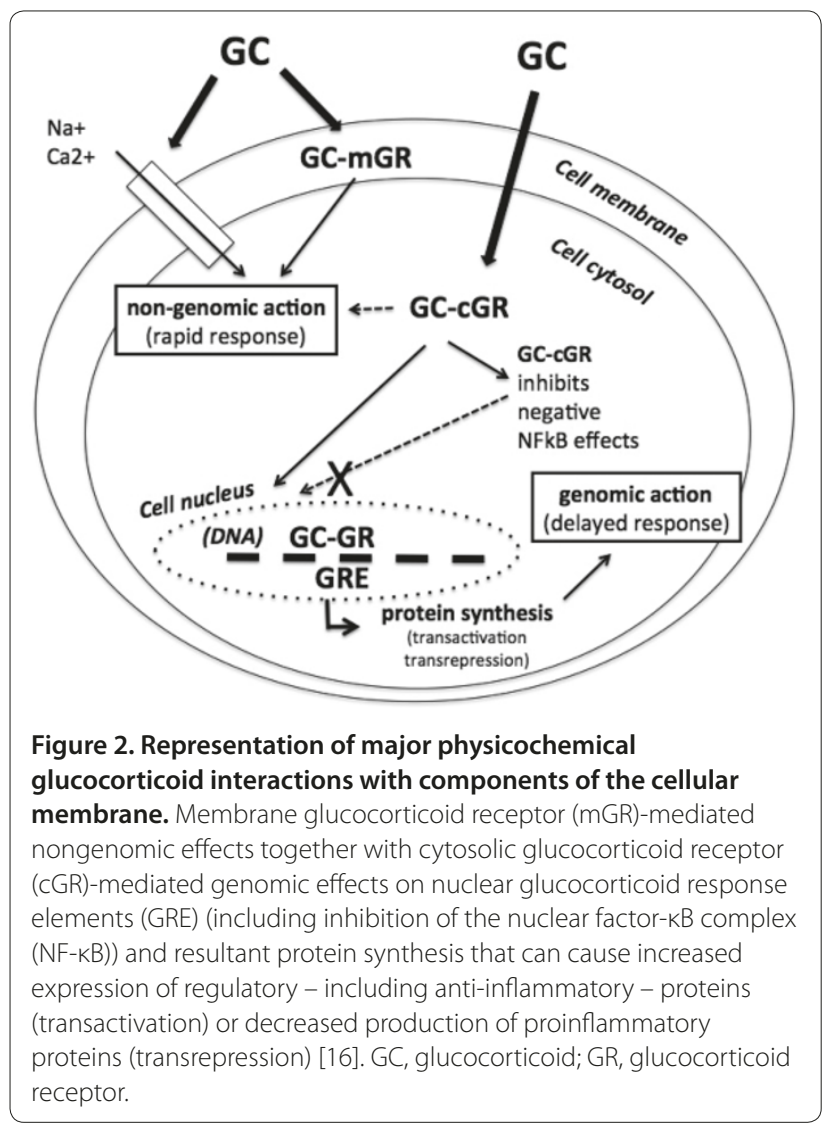

morning dose [34]. The authors stated that their clinical practice of treating all patients with $7.5 \mathrm{mg}$ /day or less was based on 'observations made in the course of studying the phenomenon of morning stiffness' $[35,36]$.

In addition to the clinical efficacy of the low dose, the authors observed that overall $50 \%$ of RA patients preferred the evening dose and concluded that low-dose GC therapy (5 $\mathrm{mg}$ prednisolone) at night was more efficacious than the morning dose for management of most RA patients.

No clinical trials involving low-dose prednisone were performed until 19 years later when a well-performed, double-blind study was published in the early 1980s [37]. This study was very important since prednisone $(5 \mathrm{mg} /$ day) was taken every morning and added to other drugs in 18 RA patients. Sixteen RA patients were given a placebo in this double-blind study. After 24 weeks, all patients were treated with placebo. Slight functional improvement was noted in the prednisone group during the 24-week period, but deterioration after switching to placebo was sustained for at least 8 weeks. Interestingly, progression of hand erosions occurred in one prednisone-treated patient and in four controls. The authors concluded that low doses of prednisone may be useful as bridge therapy between nonsteroidal anti-inflammatory therapy and use of DMARDs. 
Today there is clear evidence that GC therapy, especially long-term, low-dose treatment, slows down radiographic progression by at least $50 \%$ when given to patients with early RA, thus satisfying the conventional definition of a DMARD [38]. In addition, long-term follow-up data suggest that treatment strategies which include GC therapy may favorably alter the disease course even after discontinuation of the GCs. Some recent studies such as the Better Anti-rheumatic Farmacotherapy (BARFOT) study, the Utrecht study, the Behandel Strategieen (BeSt) study and the oldest Combination Therapy with RA (COBRA) study have now reported follow-up for more than 2 years [39-48]. More recently, inclusion of low-dose prednisone in a methotrexate-based treatment strategy for tight control in early RA improved patient outcomes [49].

In conclusion, is now possible to state there is clear evidence that low-dose, long-term GC therapy slows radiographic progression by at least $50 \%$ in treated early RA patients and therefore GCs exert disease-modifying effects [50-52].

\section{The supplementary therapeutic DMARD role of low-dose glucocorticoids}

Stressful/inflammatory conditions activate the immune system and subsequently the HPA axis through the central and peripheral production of cytokines such as IL-6 and TNF $\alpha$ [53]. A relative adrenal hypofunction, as evidenced by inappropriately normal/low serum cortisol levels and reduced sulfated dehydroepiandrosterone sulphate serum levels, seems to play an important role in the pathogenesis of autoimmune/inflammatory diseases such as RA as well as polymyalgia rheumatica [54,55]. On the other hand, chronic inflammation represents a stimulus for the activation of the stress response system (in particular, adrenal gland) and, over the long term, a subclinical hypofunction of the adrenal glands.

The regular observation of reduced cortisol and adrenal androgen secretion during testing in RA patients not treated with GCs should therefore clearly be regarded as relative adrenal insufficiency in the setting of a sustained inflammatory process, as shown by high IL-6 levels [56]. The circadian changes in the metabolism or nocturnal secretion of endogenous GCs (reduction) observed in RA patients are responsible, in part, for the time-dependent changes that are observed in the inflammatory response and related early morning clinical symptoms of the disease [57].

Melatonin, another circadian nocturnal hormone that is the secretory product of the pineal gland, has been implicated in the time-dependent RA inflammatory reaction with effects that are opposite to those of GC. As a consequence, altered functioning of the HPA axis (early morning reduced cortisol production) and of the pineal gland (night increased melatonin production) found in RA patients seems to be important in the appearance and perpetuation of the clinical circadian symptoms of the disease [57].

Consistently, human proinflammatory cytokine production (for example, TNF $\alpha$, IL-6, IL-1) exhibits a diurnal rhythmicity with peak levels during the night and early morning, at a time when plasma cortisol is lowest and melatonin levels are highest [58]. In addition, the HPA axis with the major hormone cortisol and the sympathetic nervous system with epinephrine/norepinephrine induce a shift from energy storage to energy utilization by inducing gluconeogenesis, glycogenolysis, and lipolysis [59]. Since both systems are activated during an acute inflammatory process, they serve the body by provision of energy-rich substrates [60].

The clinical and biochemical improvement observed after GC therapy in patients with RA and polymyalgia rheumatica might thus be attributed to a direct dampening of proinflammatory factors as well as to the restoration of the steroid milieu, a sort of GC replacement therapy [61].

\section{Conclusions}

Although the Mayo Clinic group that discovered GCs already recommended in 1955 that doses equivalent to 5 to $10 \mathrm{mg} /$ day prednisone should be used in treatment of RA, much higher dosages have been employed for decades, until a recent reevaluation of low doses. GCs (low dose) during long-term treatment of RA provide most of their effects through a genomic action using the cGR and then interacting with the target genes that can result in increased expression of regulatory - including anti-inflammatory - proteins (transactivation) or decreased production of proinflammatory proteins (transrepression). An inadequate secretion of GCs from the adrenal gland, in relation to chronic inflammation, seems to play an important role in the pathogenesis and disease progression of RA. Long-term follow-up data now suggest that, especially in early RA patients, treatment strategies that include low-dose GC therapy (replacement therapy) - better if respecting the circadian endogenous production rhythm - may favorably alter the disease course, contributing to the DMARD action, and this effect persists even after their discontinuation $[62,63]$.

\section{Key messages}

- The management of RA is primarily based on the use of DMARDs, mainly consisting of synthetic chemical compounds (synthetic DMARDs) and biological agents (biological DMARDs).

- An inadequate secretion of GCs from the adrenal gland, in relation to chronic inflammation, seems to 
play an important role in the pathogenesis and disease progression of RA [7].

- GC therapy, especially long-term, low-dose treatment (replacement therapy), slows down radiographic progression by at least $50 \%$ when given to patients with early RA, hence satisfying the conventional definition of a DMARD.

- GCs low-dose and long-term provide most of their effects through a genomic action using the cGR and then interacting with the target genes that can result in increased expression of regulatory - including antiinflammatory - proteins (transactivation) or decreased production of proinflammatory proteins (transrepression).

- Several long-term follow-up studies suggest that RA treatment strategies which include GC therapy may favorably alter the disease course even after their discontinuation.

- A low-dose, modified-release formulation of prednisone, administered in the evening, has been developed to counteract the circadian rise in proinflammatory cytokine levels that contributes to disease activity and might represent the way to further optimize the DMARD activity exerted by GCs in RA.

\section{Abbreviations}

cGR, cytosolic glucocorticoid receptor; DMARD, disease-modifying

antirheumatic drug; GC, glucocorticoid; HPA, hypothalamic-pituitary-adrenal; IL, interleukin; RA, rheumatoid arthritis; TNF, tumour necrosis factor.

\section{Competing interests}

MC received funds for clinical research from Horizon and Mundipharma.

The other authors declare that they have no competing interests.

\section{Author details}

'Research Laboratory and Academic Division of Clinical Rheumatology, Department of Internal Medicine, University of Genova, Viale Benedetto XV 6 , 16132 Genova, Italy. ${ }^{2}$ Department of Rheumatology and Clinical Immunology, Charité - Universitätsmedizin Berlin, Charitéplatz 1, 10117 Berlin, Germany.

\section{Declaration}

This article has been published as part of Arthritis Research \& Therapy Volume 16 Suppl 2, 2014: At the interface between immunology and endocrinology in rheumatic diseases. The full contents of the supplement are available at http://arthritis-research.com/supplements/16/S2.

This supplement was proposed, developed and commissioned by Arthritis Research \& Therapy and was funded by an educational grant from Horizon Pharma Inc. All published articles were independently prepared by the authors and have undergone peer review in accordance with the journal's standard policies and processes. Horizon Pharma Inc had no input into the topics covered or the articles themselves. The Supplement Editor was appointed by the journal and declares that they have no competing interests.

Published: 13 November 2014

\section{References}

1. McInnes IB, O'Dell JR: State-of-the-art: rheumatoid arthritis. Ann Rheum Dis 2010, 69:1898-1906

2. Aletaha D, Neogi T, Silman AJ, Funovits J, Felson DT, Bingham CO $3^{\text {rd }}$, Birnbaum NS, Burmester GR, Bykerk VP, Cohen MD, Combe B, Costenbader KH, Dougados M, Emery P, Ferraccioli G, Hazes JM, Hobbs K, Huizinga TW, Kavanaugh A, Kay J, Kvien TK, Laing T, Mease P, Ménard HA, Moreland LW, Naden RL, Pincus T, Smolen JS, Stanislawska-Biernat E, Symmons D, et al: 2010 Rheumatoid arthritis classification criteria: an American College of Rheumatology/European
League Against Rheumatism collaborative initiative. Arthritis Rheum 2010, 62:2569-2581.

3. Berglin E, Dahlqvist SR: Comparison of the 1987 ACR and 2010 ACR/EULAR classification criteria for rheumatoid arthritis in clinical practice: a prospective cohort study. Scand J Rheumato/ 2013, 42:362-368.

4. McInnes IB, Schett G: The pathogenesis of rheumatoid arthritis. N Engl J Med 2011, 365:2205-2219.

5. Ceccarelli F, Perricone C, Trotta F, Cuomo G, Pellerito R, Bagnato G, Salaffi F, Caporali R, Cutolo M, Galeazzi M, Fiocco U, Lapadula G, Bombardieri S, Bianchi G, Gorla R, Giardina AR, Gallo G, Giardino AM, Valesini G; Arpa Study Group: Remission in early, aggressive rheumatoid arthritis: a multicentre prospective observational Italian study ARPA (Artrite Reumatoide Precoce Aggressiva). Clin Exp Rheumatol 2013, 31:341-349.

6. Smolen JS, van der Heijde D, Machold KP, Aletaha D, Landewé R: Proposal for a new nomenclature of disease-modifying antirheumatic drugs. Ann Rheum Dis 2014,73:3-5.

7. Svensson B, Boonen A, Albertsson K, van der Heijde D, Keller C, Hafstrom I: Lowdose prednisolone in addition to the initial disease-modifying antirheumatic drug in patients with early active rheumatoid arthritis reduces joint destruction and increases the remission rate: a two-year randomized trial. Arthritis Rheum 2005, 52:3360-3370.

8. Smolen JS, Landewé R, Breedveld FC, Buch M, Burmester G, Dougados M, Emery P, Gaujoux-Viala C, Gossec L, Nam J, Ramiro S, Winthrop K, de Wit M, Aletaha D, Betteridge N, Bijlsma JW, Boers M, Buttgereit F, Combe B, Cutolo M, Damjanov N, Hazes JM, Kouloumas M, Kvien Tk, Mariette X, Pavelka K, van Riel PL, Rubbert-Roth A, Scholte-Voshaar M, Scott DL, et al:: EULAR recommendations for the management of rheumatoid arthritis with synthetic and biological diseasemodifying antirheumatic drugs: 2013 update. Ann Rheum Dis 2014, 73:492-509.

9. Newton R: Anti-inflammatory glucocorticoids: changing concept. Eur J Pharmacol 2014, 724:231-236.

10. Stellato C: Posttranscriptional gene regulation: novel pathways for glucocorticoids' anti-inflammatory action. Trans/ Med UniSa 2012, 3:67-73,

11. Strehl C, Spies CM, Buttgereit F: Pharmacodynamics of glucocorticoids. Clin Exp Rheumatol 2011, 29(5 Suppl 68):S13-S18.

12. Buttgereit F, da Silva JA, Boers M, Burmester GR, Cutolo M, Jacobs J, Kirwan J, Kohler L, Van Riel P, Vischer T, Bij|sma JW: Standardised nomenclature for glucocorticoid dosages and glucocorticoid treatment regimens: current questions and tentative answers in rheumatology. Ann Rheum Dis 2002, 61:718-722.

13. Almawi WY, Melemedjian OK: Molecular mechanisms of glucocorticoid antiproliferative effects: antagonism of transcription factor activity by glucocorticoid receptor. J Leukocyte Biol 2002, 71:9-15.

14. Pratt WB: The hsp90-based chaperone system: involvement in signal transduction from a variety of hormone and growth factor receptors. Proc Soc Exp Biol Med 1998, 217:420-434.

15. Jensen LB, Magnussson E, Gunnarsson L, Vermehren C, Nielsen HM, Petersson K: Corticosteroid solubility and lipid polarity control release from solid lipid nanoparticles. Int J Pharm 2010, 390:53-60

16. Stahn C, Buttgereit F: Genomic and nongenomic effects of glucocorticoids. Nat Clin Pract Rheumatol 2008, 4:525-533.

17. Barnes PJ: Anti-inflammatory actions of glucocorticoids: molecular mechanisms. Clin Sci 1998, 94:557-572.

18. Spies CM, Bij|sma JW, Burmester GR, Buttgereit F: Pharmacology of glucocorticoids in rheumatoid arthritis. Curr Opin Pharmacol 2010, 10:302-307.

19. Coutinho AE, Chapman KE: The anti-inflammatory and immunosuppressive effects of glucocorticoids, recent developments and mechanistic insights. Mol Cell Endocrinol 2011, 335:2-13.

20. Alten R, Döring G, Cutolo M, Gromnica-Ihle E, Witte S, Straub R, Buttgereit F: Hypothalamus-pituitary-adrenal axis function in patients with rheumatoid arthritis treated with nighttime-release prednisone. J Rheumato/ 2010, 37:2025-2031.

21. Buttgereit F, Mehta D, Kirwan J, Szechinski J, Boers M, Alten RE, SuproniK J, Szombati I, Romer U, Witte S, Saag KG: Low-dose prednisone chronotherapy for rheumatoid arthritis: a randomised clinical trial (CAPRA-2). Ann Rheum Dis 2013, 72:204-210.

22. Cutolo M, laccarino L, Doria A, Govoni M, Sulli A, Marcassa C: Efficacy of the switch to modified-release prednisone in rheumatoid arthritis patients treated with standard glucocorticoids. Clin Exp Rheumatol 2013, 31:498-505.

23. Buttgereit F, Scheffold A: Rapid glucocorticoid effects on immune cells. Steroids 2002, 67:529-534. 
24. Duru N, van der Goes MC, Jacobs JW, Andrews T, Boers M, Buttgereit F, Caeyers N, Cutolo M, Halliday S, Da Silva JA, Kirwan JR, Ray D, Rovensky J, Severijns G, Westhovens R, Bijlsma JW: EULAR evidence-based and consensus-based recommendations on the management of medium to high-dose glucocorticoid therapy in rheumatic diseases. Ann Rheum Dis 2013, 72:1905-1913.

25. Buttgereit F, Saag KG, Cutolo M, da Silva JA, Bijlsma JW: The molecular basis for the effectiveness, toxicity, and resistance to glucocorticoids: focus on the treatment of rheumatoid arthritis. Scand J Rheumatol 2005, 34:14-21.

26. Song $\Vdash H$, Buttgereit F: Non-genomic glucocorticoid effects to provide the basis for new drug developments. Mol Cell Endocrino/ 2006, 246:142-146.

27. Cutolo M: Chronobiology and the treatment of rheumatoid arthritis. Curr Opin Rheumatol 2012, 24:312-318.

28. Cutolo M: Rheumatoid arthritis: circadian and circannual rhythms in RA. Nat Rev Rheumatol 2011, 7:500-502.

29. Strehl C, Spies CM, Buttgereit F: Pharmacodynamics of glucocorticoids. Clin Exp Rheumatol 2011, 29(5 Suppl 68):S13-S18.

30. Spies CM, Cutolo M, Straub RH, Burmester GR, Buttgereit F: Prednisone chronotherapy. Clin Exp Rheumatol 2011, 29(5 Suppl 68):S42-S45

31. Polley HF, Slocumb CH, Ward LE, Hench PS. Recognition and treatment of patients with chronic hypercortisonism. Ann Rheum Dis 1955, 14:416-417.

32. Empire Rheumatism Council: Multi-centre controlled trial comparing cortisone acetate and acetyl salicylic acid in the long-term treatment of rheumatoid arthritis. Results up to one year. Ann Rheum Dis 1955, 14:353-367.

33. Empire Rheumatism Council: Multi-centre controlled trial comparing cortisone acetate and acetyl salicylic acid in the long-term treatment of rheumatoid arthritis. Results of three years treatment. Ann Rheum Dis 1957, 16:277-289.

34. de Andrade JR, McCormick JN, Hill AGS: Small doses of prednisolone in the management of rheumatoid arthritis. Ann Rheum Dis 1964, 23:158-162.

35. Pincus T, Cutolo M: Clinical trials documenting the efficacy of low-dose glucocorticoids in rheumatoid arthritis. Neuroimmunomodulation 2015 22:46-50.

36. Pincus T, Bijlsma JW, Braun J, Buttgereit F, Cutolo M: Low-dose glucocorticoids in rheumatic diseases: introduction. Clin Exp Rheumatol 2011, 29(5 Suppl 68):S2-S4.

37. Harris ED, Jr, Emkey RD, Nichols JE, Newberg A: Low dose prednisone therapy in rheumatoid arthritis: a double blind study. J Rheumatol 1983, 10:713-721.

38. Bijlsma JW: Disease control with glucocorticoid therapy in rheumatoid arthritis. Rheumatology (Oxford) 2012, 51(Suppl 4):iv9-iv13.

39. Hafström I, Albertsson K, Boonen A, van der Heijde D, Landewé R, Svensson B; BARFOT Study Group: Remission achieved after 2 years treatment with lowdose prednisolone in addition to disease-modifying anti-rheumatic drugs in early rheumatoid arthritis is associated with reduced joint destruction still present after 4 years: an open 2-year continuation study. Ann Rheum Dis 2009 68:508-513.

40. Jacobs JW, van Everdingen AA, Verstappen SM, Bijlsma JW: Follow up radiographic data on patients with rheumatoid arthritis who participated in a two-year trial of prednisone therapy or placebo. Arthritis Rheum 2006, 54:1422-1428.

41. Klarenbeek NB, Guler-Yuksel M, van der Kooij SM, Han KH, Ronday HK, Kerstens PJ, Seys PE, Huizinga TW, Dijkmans BA, Allaart CF: The impact of four dynamic, goal-steered treatment strategies on the 5-year outcomes of rheumatoid arthritis patients in the BeSt sudy. Ann Rheum Dis 2011, 70:1039-1046.

42. van Tuyl LHD, Boers M, Lems WF, Landewe RB, Han H, van der Linden S, van de Laar M, Westhovens R, van Denderen JC, Westedt ML, Peeters AJ, Jacobs P, Huizinga TW, van de Brink H, Dijkmans BA, Voskuyl AE: Survival, comorbidities and joint damage 11 years after the COBRA combination therapy trial in early rheumatoid arthritis. Ann Rheum Dis 2010, 69:807-812.

43. Bakker MF, Jacobs JW, Welsing PM, Verstappen SM, Tekstra J, Ton E, Geurts MA, van der Werf JH, van Albada-Kuipers GA, Jahangier-de Veen ZN, van der Veen MJ, Verhoef CM, Lafeber FP, Bijlsma JW; Utrecht Rheumatoid Arthritis Cohort Study Group: Low-dose prednisone inclusion in a methotrexate-based, tight control strategy for early rheumatoid arthritis: a randomized trial. Ann Intern Med 2012, 156:329-339.

44. Svensson B, Boonen A, Albertsson K, van der Heijde D, Keller C, Hafstrom I: Lowdose prednisolone in addition to the initial disease-modifying antirheumatic drug in patients with early active rheumatoid arthritis reduces joint destruction and increases the remission rate: a two-year randomized trial. Arthritis Rheum 2005, 52:3360-3370.

45. van Everdingen AA, Jacobs JW, Siewertsz Van Reesema DR, Bijlsma JW: Low-dose prednisone therapy for patients with early active rheumatoid arthritis: clinical efficacy, disease-modifying properties, and side effects: a randomized, double-blind, placebo-controlled clinical trial. Ann Intern Med 2002, 136:1-12.

46. Goekoop-Ruiterman YPM, Vries-Bouwstra JK, Allaart CF, van Zeben D, Kerstens PJ, Hazes JM, Zwinderman AH, Ronday HK, Han KH, Westedt ML, Gerards AH, van Groenendael JH, Lems WF, van Krugten MV, Breedveld FC, Dijkmans BA: Clinical and radiographic outcomes of four different treatment strategies in patients with early rheumatoid arthritis (the BeSt study). A randomized, controlled trial. Arthritis Rheum 2005, 52:3381-3390.

47. Boers M, Verhoeven AC, Markusse HM, van de Laar MA, Westhovens R, van Denderen JC, van Zeben D, Dijkmans BA, Peeters AJ, Jacobs P, van den Brink HR, Schouten HJ, van der Heijde DM, Boonen A, van der Linden S: Randomised comparison of combined step-down prednisolone, methotrexate and sulphasalazine with sulphasalazine alone in early rheumatoid arthritis. Lancet 1997, 350:309-318.

48. Landewé RB, Boers M, Verhoeven AC, Westhovens $R$, van de Laar MA, Markusse HM, van Denderen JC, Westedt ML, Peeters AJ, Dijkmans BA, Jacobs P, Boonen A, van der Heijde DM, van der Linden S: COBRA combination therapy in patients with early rheumatoid arthritis: long-term structural benefits of a brief intervention. Arthritis Rheum 2002, 46:347-356.

49. van Tuyl LHD, Boers M, Lems WF, Landewé RB, Han $H$, van der Linden S, van de Laar M, Westhovens R, van Denderen JC, Westedt ML, Peeters AJ, Jacobs P, Huizinga TW, van de Brink H, Dijmans BA, Voskuyl AE: Survival, comorbidities and joint damage 11 years after the COBRA combination therapy trial in early rheumatoid arthritis. Ann Rheum Dis 2010, 69:807-812.

50. Cutolo M, Chrousos GP, Pincus T: Special issue on glucocorticoid therapy in rheumatic diseases: introduction. Neuroimmunomodulation 2015, 22:3-5.

51. Pincus T, Sokka T, Castrejón I, Cutolo M: Decline of mean initial prednisone dosage from 10.3 to $3.6 \mathrm{mg} /$ day to treat rheumatoid arthritis between 1980 and 2004 in one clinical setting, with long-term effectiveness of dosages less than 5 mg/day. Arthritis Care Res (Hoboken) 2013, 65:729-736.

52. Cutolo M, Buttgereit F, Straub RH: Regulation of glucocorticoids by the central nervous system. Clin Exp Rheumatol 2011, 29(5 Suppl 68):S-19-S-22.

53. Kanczkowski W, Alexaki VI, Tran N, Großklaus S, Zacharowski K, Martinez A, Popovics P, Block NL, Chavakis T, Schally AV, Bornstein SR. Hypothalamo-pituitary and immune-dependent adrenal regulation during systemic inflammation. Proc Natl Acad Sci USA 2013, 110:14801-14806.

54. Cutolo M, Foppiani L, Minuto F: Hypothalamic-pituitary-adrenal axis impairment in the pathogenesis of rheumatoid arthritis and polymyalgia rheumatica. J Endocrinol Invest 2002, 25(10 Suppl):19-23.

55. Cutolo M, Straub RH: Polymyalgia rheumatica: evidence for a hypothalamicpituitary-adrenal axis-driven disease. Clin Exp Rheumatol 2000, 18:655-658.

56. Cutolo M, Sulli A, Pizzorni C, Craviotto C, Straub RH: Hypothalamic-pituitaryadrenocortical and gonadal functions in rheumatoid arthritis. Ann N Y Acad SCi 2003, 992:107-117.

57. Cutolo M, Villaggio B, Otsa K, Aakre O, Sulli A, Seriolo B: Altered circadian rhythms in rheumatoid arthritis patients play a role in the disease's symptoms. Autoimmun Rev 2005, 4:497-502.

58. Yoshida K, Hashimoto T, Sakai Y, Hashiramoto A: Involvement of the circadian rhythm and inflammatory cytokines in the pathogenesis of rheumatoid arthritis. J Immunol Res 2014, 2014:282495.

59. Straub RH, Cutolo $M$, Buttegreit F, Pongratz G: Energy regulation and neuroendocrine-immune control in chronic inflammatory diseases. J Intern Med 2010, 267:543-560

60. Straub RH1, Buttgereit F, Cutolo M: Alterations of the hypothalamic-pituitaryadrenal axis in systemic immune diseases - a role for misguided energy regulation. Clin Exp Rheumato/ 2011, 29(5 Suppl 68):S23-S31.

61. Cutolo M: Hormone therapy in rheumatic diseases. Curr Opin Rheumatol 2010, 22:257-263.

62. Spies CM, Cutolo M, Straub RH, Burmester GR, Buttgereit F: Prednisone chronotherapy. Clin Exp Rheumatol 2011, 29(5 Suppl 68):S42-S45.

63. Clarke LL, Jessop DS, Hunt LP, Straub RH, Perry MG, Kirwan JR: Alleviation of morning joint stiffness by low-dose prednisone in rheumatoid arthritis is associated with circadian changes in IL-6 and cortisol. Int J Clin Rheumato/ 2011, $6: 241-249$

doi:10.1186/ar4685

Cite this article as: Cutolo M, et al:: The supplementary therapeutic DMARD role of low-dose glucocorticoids in rheumatoid arthritis. Arthritis Research \& Therapy 2014, 16(Suppl 2):S1. 